\title{
How do Housing Prices and Business Cycles Interact in Spain? An Empirical Analysis
}

\author{
MERCÈ SALA-RIOS ${ }^{\text {a }}$, MARIONA FARRÉ-PERDIGUER ${ }^{a}$, TERESA TORRES-SOLÉ $^{\text {a }}$ \\ a University of Lleida, Faculty of Law and Economics, Carrer de Jaume II, 73. Campus Cappont. 25001 \\ Lleida, Spain.E-mail: mercesa@econap.udl.cat; mariona.farre@econap.udl.cat; torres@econap.udl.cat
}

\begin{abstract}
We analyze the relationship between business cycles and housing price cycles in Spain over the 1971-1Q/2016-1Q period. Specifically, the question that we want to address is: do the features of the Spanish business cycles and the housing price cycles confer a synchronized nature on them? The study follows three steps. First, we identify the turning points of both cycles. Second, we focus on synchronization and causality indicators. Finally, we document the economic facts that lie behind the relationship found. Overall, business cycles are longer than housing price cycles, although this is more evident in expansion than in contraction phases. Furthermore, housing price cycles seem to be more sensitive to shocks than business cycle.
\end{abstract}

Keywords: Business Cycle, Housing Prices, Turning Points, Synchronization.

\section{¿Cómo interactúan los precios de la vivienda y el ciclo económico en España? Un análisis empírico}

\section{RESUMEN}

El trabajo analiza la relación entre los ciclos económicos y los ciclos del precio de la vivienda en España durante el período 1971-1Q/2016-1Q. La pregunta que queremos abordar es: ¿las características de los ciclos económicos españoles y los ciclos del precio de la vivienda les confieren una naturaleza sincronizada? El estudio avanza a través de tres análisis. Primero, se identifican los puntos de inflexión de ambos ciclos. Segundo, calculamos el nivel de sincronización y la causalidad. Finalmente, exponemos los hechos económicos que determinan la relación encontrada en los puntos anteriores. En general, los ciclos económicos son más largos que los ciclos del precio de la vivienda, siendo más evidente en la expansión que en la contracción. Además, los ciclos del precio de la vivienda son más sensibles a los shocks que el ciclo económico.

Palabras clave: Ciclo económico, precios de la vivienda, puntos de giro, sincronización.

JEL Classification: E32, L74, N64, O52

Artículo recibido en enero de 2018 y aceptado en julio de 2018

Artículo disponible en versión electrónica en la página www.revista-eea.net, ref. ə-36303 


\section{INTRODUCTION}

The Spanish housing market and the construction sector experienced sustained growth in house building, home sales and housing prices from the late 1990s to mid-2007. The financial crisis and the bubble of the housing market ended this increasing tendency. This boom and its causes have been studied extensively ${ }^{1}$, not only because of the severity of the banking and housing crisis but also because housing and the activities related to it are among the main sources of the Spanish economic growth. In this sense, during the period 1995-2006, on average the construction gross fixed capital formation explained $16.8 \%$ of the Spanish GDP, housing gross fixed capital formation roughly $8.7 \%$ and other activities related to the real estate sector $6 \%$. It is worth stressing that the housing macroeconomic variables, even after the 2007 crisis, remain at the core of the Spanish economy. In the period 2007-2015, the above percentages were $13.7 \%, 6.7 \%$ and $9.6 \%$, respectively.

The frame described highlights a number of questions about the linkage between economic activity and housing markets. Specifically, the question that we want to address in this paper is: do the features of the Spanish business cycles and the housing price cycles confer a synchronized nature on them? To tackle this question, we undertake an assessment of the relationship between business cycles and housing price cycles in Spain over the 1971-1Q/2016-1Q period.

The study follows three steps. First, we identify the turning points of economic activity and housing prices to analyze the main features of their cycles. Second, we examine how these features affect their interaction. We focus on synchronization and causality indicators. We study the (lagging/leading) causality between cycles using the Granger causality test. Since the results seem to indicate a different leading/lagging linkage in each cyclical phase of the housing prices, expansion and contraction, we estimate two alternative models. The first of them takes housing prices as the reference series and identifies the causality between the housing price expansion phases and the values of the business cycle in these quarters. The second model again takes prices as the reference series and estimates the causality between the housing price contraction phases and the values of the business cycle in these quarters. Finally, we document the economic facts that lie behind the relationship found.

This paper contributes to the empirical literature in different ways. First, the importance of the real estate and construction sectors in the Spanish economy and their impact during the crisis initiated in the middle of 2007 reopened the debate regarding whether the housing market replies to understandable economic

\footnotetext{
${ }^{1}$ See, for instance, García-Montalvo (2009), Akin et al. (2014), Rubio and Carrasco-Gallego (2017) or Blanco et al. (2016) for a disaggregated territorial analysis.
} 
behavior. Housing prices are one of the most crucial Spanish housing market variables, which means that their fluctuations should be analyzed and put into relation to the economic activity. In this sense our study is a detailed country empirical analysis addressing this relationship over a long period of time with a well-established methodology. Second, any future line of enquiry that seeks to model the interactions between housing prices and economic factors in Spain will require an adequate understanding of the housing price cycle's features, which can be provided by the results presented in this study. Third, policymakers have an interest in knowing the features of the housing price cycles, because they are essential in the definition of efficient economic policy measures. It is also necessary to determine the linkage between housing prices and business cycles to redirect or avoid future unwanted fluctuations.

We summarize the main results in the following. First, business cycles are longer than housing price cycles overall, although this is more evident in expansion than in contraction phases. Furthermore, housing price cycles seem to be more sensitive to shocks than business cycles, especially in the recovery processes. Second, we find that housing price co-movements are pro-cyclical but neither contemporaneous nor homogeneous. Third, the Granger causality and the estimations point out that the housing price cycle leads the business cycle in expansion phases and that both cycles are well synchronized in contraction phases.

Our study is related to the extensive literature on housing prices. For instance, the "fundamentals" of the housing price fluctuations are examined by a large number of papers. Factors such as interest rates, inflation levels, economic growth, wealth, household incomes and unemployment rates, among others, are included as determinants of housing prices. Without wishing to present a thorough review, we point out the following interesting empirical studies in this field: Claessens et al. (2009); Agnello and Schuknecht (2011); Hirata et al. (2012); Corradin and Fontana (2013); Bracke (2013); Ling et al. (2015); Damen et al. (2016); Engsted et al. (2016); Huber (2016); Huang (2017); and Kishor and Marfatia (2017). The housing price determinants in Spain are analyzed, for instance, by García-Montalvo (2001) and Martínez and Maza (2003). As the most important determinants they indicate income, youth unemployment, the residential capital user cost, the stock of housing and the stock exchange return.

The linkages between housing markets and business cycles are assessed, among others, by the following studies: Catte et al. (2004); Ceron and Suarez (2006); Leamer (2008, 2009, 2015); Álvarez et al. (2009); Ferrara and Vigna (2009); Dufrénot and Malik (2010); Igan et al. (2011); and Hirata et al. (2012); Kydland et al. (2016); Vogiazas and Alexiou (2017); and Mian et al. (2017). The cyclical properties of Spanish real and nominal housing-related variables are analyzed by Álvarez and Cabrero (2010). They find that residential investment is 
linked to a greater extent to future output than contemporaneous output. This leading behavior is larger in expansions than in contractions. The authors also remark that contractions in the GDP and housing real variables appear to be briefer than expansions.

The paper is structured as follows. Section 2 presents our data and explains our selection of variables. Section 3 is focused on the turning points and on the features of the business and housing price cycles. Section 4 analyzes the synchronization and causality relationship. Section 5 documents the economic facts that lie behind the relationship found in the previous section. We conclude in Section 6.

\section{DATA}

Our study is based on the "deviation cycle" due to the fact that the analysis is built on the fluctuations in the series levels with respect to the trend. The cyclical component (c) is the deviation of the original series with respect to the trend, and it determines the cyclical fluctuations and their turning points, peaks (P) and troughs (T). We compute (c) using the Hodrick-Prescott filter. We identify two phases in the cycle, expansion and contraction. During expansions the cyclical component increases, and during recessions it contracts.

The data set used in this paper covers 45 years with a quarterly frequency. We analyze the interactions between the housing prices and the business cycles during the period 1971-1Q/2016-1Q. The sources of the data are the Bank for International Settlements for the housing prices (HP) and the Instituto Nacional de Estadística (INE) for the business cycle.

The GDP is the business cycle indicator. The INE GDP data, base year 2010, begins in 1995-1Q. To have a long-run quarterly series encompassing the period 1971-1Q to 2016-1Q with the INE base year 2010, we rescale the INE series 1971-1Q/1997-4Q with the base year 1986, using the linked series of De La Fuente (2016). The period 1995-1Q/1997-4Q presents data in both series (1986 and 2010 base years), so the correlation index between the rescaled quarterly series and the INE quarterly series with the base year 2010 is calculated. The correlation index reaches a value of 0.89 and is an indicator of the goodness of the rescaled series.

All the variables are at the quarterly frequency, in real terms (deflated by the GDP deflator), in log levels and seasonally adjusted. Therefore, throughout the study, the HP and GDP are the log levels of the cyclical components of the samples in real terms. 


\section{LENGTH AND DEPTH OF EXPANSION AND CONTRACTION PHASES}

The aim of this section is to discern whether the business cycles and the housing price cycles present different features that confer on them an unsynchronized nature. The analysis is initiated by dating the turning points by means of a non-parametric methodology proposed by Bry and Boschan (1971) and adapted to quarterly data by Harding and Pagan (2002). The method involves firstly determining the local maximum/minimum in the series. A local maximum/minimum is defined as the highest/lowest point between the two preceding and following quarters to its position: $\mathrm{y}_{\mathrm{t}}$ is a peak at time $\mathrm{t}$ if $\mathrm{y}_{\mathrm{t}}$ is the maximum $\left(\mathrm{y}_{\mathrm{t}-2} \ldots . \mathrm{y}_{\mathrm{t}+2}\right) ; \mathrm{y}_{\mathrm{t}}$ is a trough if $\mathrm{y}_{\mathrm{t}}$ is the minimum $\left(\mathrm{y}_{\mathrm{t}-2} \ldots \mathrm{y}_{\mathrm{t}+2}\right)$. Secondly, a peak must be followed by a trough and vice versa to ensure that only completed cycles may be used. Finally, the minimum phase length is three quarters and the minimum complete cycle length is five quarters ${ }^{2}$.

To characterize the length and the depth of expansions and contractions, we consider the duration, amplitude and deepness of the phases. The duration (D) of a contraction (expansion) is the number of quarters that elapse between a peak and the next trough (trough and peak). The amplitude of a contraction (expansion) is calculated as the percentage change between the cyclical component value in the trough (peak) and the value in the previous peak (trough). The amplitude estimates the gains in terms of production (prices) in expansion phases and the losses in the contraction phases. Throughout the paper we focus on the average of the duration and amplitude.

To determine whether the duration and amplitude produce significant asymmetries between the phases, we use the deepness statistic. Deepness occurs when the troughs are deeper than the height of the peaks or vice versa, which denotes asymmetry in the distribution of a series. Following Sichel (1993) we contrast the presence of deepness using the estimation of the asymmetry coefficient $\mathrm{D}(\mathrm{c})$ :

$$
D(c)=\left[T^{-1}\left(\frac{\sum_{t}\left(c_{t}-\bar{c}\right)^{3}}{\sigma(c)^{3}}\right)\right]
$$

$\mathrm{c}_{\mathrm{t}}$ is the cyclical component (GDP and HP in this study), $\sigma(\mathrm{c})$ is the standard deviation and $\mathrm{T}$ is the size of the sample.

As the $c_{t}$ values observed are autocorrelated, we estimate $D(c)$ using the procedure suggested by Newey and West (1987) (HAC) with Bartlett weights.

\footnotetext{
${ }^{2}$ The software we employ is known as BUSY, which is developed by the European Commission (Fiorentini and Planas, 2003).
} 
The variable $\mathrm{z}_{\mathrm{t}}$, defined below, is regressed on a constant of which the estimation is the same as that for $\mathrm{D}(\mathrm{c})$. As the quotient between the constant and its standard error is asymptotically normal, the significance of $\mathrm{D}(\mathrm{c})$ can be analyzed using the values of the t-ratio.

$$
z_{t}=\frac{\left(c_{t}-\bar{c}\right)^{3}}{\sigma(c)^{3}}
$$

If the contractions are deeper than the expansions, the average value of the deviations below the average will be above the average value of the deviations above it. The series will have a negative value in this asymmetry.

Table 1 and Figures 1 and 2 present the turning points. The GDP presents six complete trough-to-trough cycles and the HP seven. The GDP captures the Spanish recessions well. The energy crises, the downturn at the beginning of the 1980s, the crisis in the 1990s and the current crisis are recognized.

Table 1

Turning points

\begin{tabular}{|c|c|c|c|c|c|}
\hline \multirow{9}{*}{ GDP } & $\mathbf{P}$ & $\begin{array}{l}\mathbf{T} \\
\end{array}$ & \multirow{9}{*}{ HP } & $\mathbf{P}$ & $\mathbf{T}$ \\
\hline & & 1972-1Q & & & 1972-4Q \\
\hline & 1975-4Q & 1977-3Q & & 1974-2Q & 1976-1Q \\
\hline & 1980-2Q & 1985-1Q & & 1978-2Q & 1986-1Q \\
\hline & 1991-2Q & 1994-1Q & & 1991-4Q & 1994-1Q \\
\hline & 1995-4Q & 1996-4Q & & 1995-3Q & 1998-1Q \\
\hline & $2000-1 Q$ & 2004-2Q & & 1999-3Q & 2001-4Q \\
\hline & 2008-1Q & 2012-4Q & & 2007-3Q & 2009-2Q \\
\hline & & & & 2010-4Q & 2013-1Q \\
\hline
\end{tabular}

Source: Own elaboration.

Table 2 provides the features of the cycles in terms of duration, amplitude and deepness. With respect to the duration, business cycles are longer than housing price cycles. However, in contraction phases there are no large differences, with the GDP and the HP phases lasting around 3 years overall, while in the expansion phases both cycles show larger differences. The housing price expansions are shorter than the business cycle expansions. The GDP expands for 14 quarters and the HP expands for 11. In addition, our results suggest that in expansion phases the amplitude of the HP is greater than that of the GDP (285.44 and 205.14, respectively) and in recession phases it is lower (270.23 versus 388.77 in absolute values). In expansion phases housing price gains are larger than gains in economic activity, and in recessions housing price losses are lower than those of economic activity. 
Figure 1

GDP turning points over the period 1971-1Q/2016-1Q

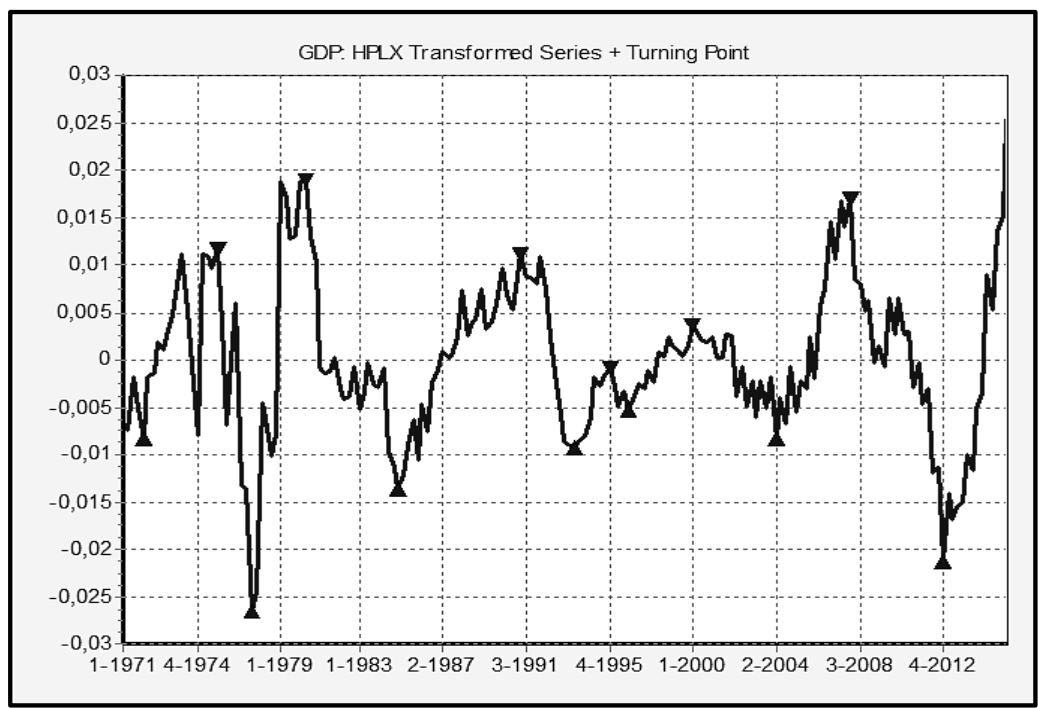

Source: BUSY.

Figure 2

HP turning points over the period 1971-1Q/2016-1Q

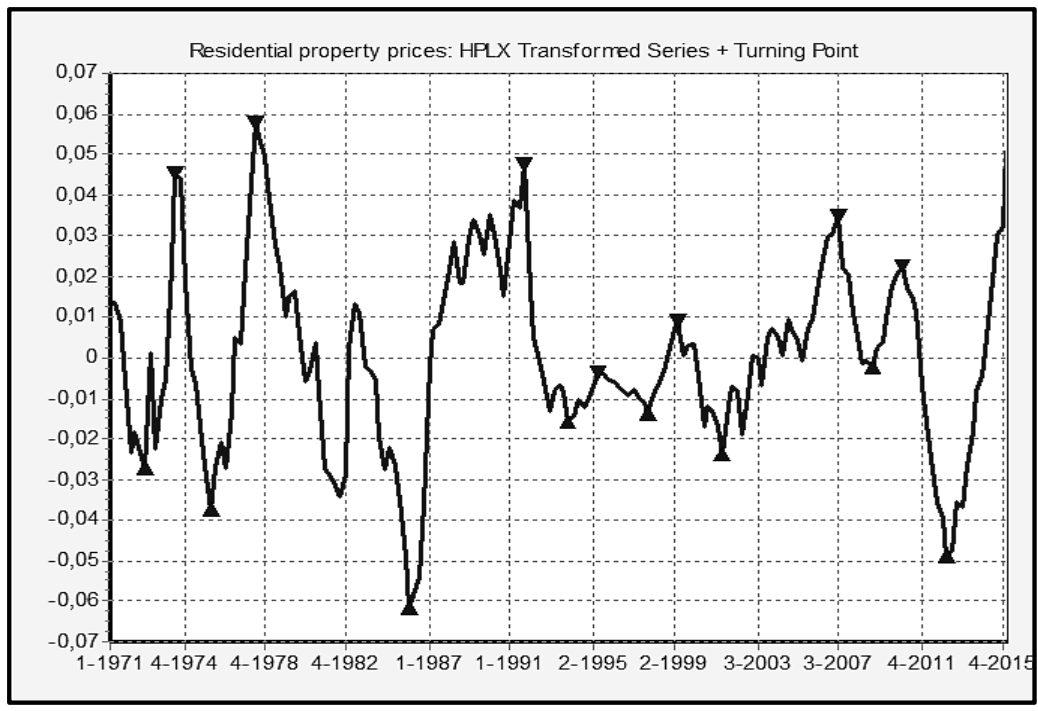

Source: BUSY. 
Table 2

Features of the cycle phases

\begin{tabular}{|l|c|c|l|c|c|}
\hline \multicolumn{2}{|l|}{ Average duration } & \multicolumn{2}{l|}{ Average amplitude } & \multirow{2}{*}{ t-deepness } \\
\cline { 1 - 5 } & P to T & T to P & P to T & T to P & \\
\hline GDP & 12.83 & 14.33 & -388.77 & 205.14 & -0.494969 \\
\hline HP & 11.71 & 11.29 & -270.23 & 285.44 & 0.358848 \\
\hline
\end{tabular}

Source: Own elaboration.

We next analyze the test proposed by Sichel (1993) to determine whether the amplitude is sufficiently significant to provide deepness asymmetry to the cycles. The sign of the deepness in Table 2 is what we expected in view of the amplitude data. By and large, the higher amplitude in GDP (HP) contraction (expansion) phases translates into a negative (positive) sign in the deepness estimation. However, the deepness asymmetry is not statistically significant.

Summarizing the results, the shorter duration and the greater (smaller) gains (losses) of the housing price phases seem to make them more sensitive than business cycles to whatever shock could affect them. Having achieved these results, it is important to consider in greater depth how they affect the interaction between the two variables, which is the aim of our empirical analysis. In the next section we turn our attention to this interaction and focus on synchronization and causality indicators.

\section{DOES A LEADING/LAGGING RELATIONSHIP EXIST?}

We analyze the correlation through various coefficients. Firstly, Harding and Pagan (2002) define synchronization as the amount of time for which two series $(\mathrm{i}, \mathrm{j})$ are in the same phase. The concordance index (I) proposed is defined as:

$$
I_{i j t}=T^{-1}\left[\sum_{t=1}^{T}\left(S_{i t} S_{j t}\right)+\sum_{t=1}^{T}\left(1-S_{i t}\right)\left(1-S_{j t}\right)\right]
$$

$\mathrm{S}_{\mathrm{it}}\left(\mathrm{S}_{\mathrm{jt}}\right)$ is a binary variable that takes the value one when $\mathrm{i}(\mathrm{j})$ is in expansion and zero when it is in contraction; $\mathrm{T}$ is the number of observations. The index varies between one and zero. One denotes perfect concordance and zero perfect absence of concordance.

Secondly, to determine whether the co-movements are statistically significant, a second analytical method is used. The correlation coefficient $(\rho)$ between $\left(S_{i t}\right)$ and $\left(S_{j t}\right)$ is estimated using the generalized method of moments (GMM) proposed by Harding and Pagan (2006). The moment condition is:

$$
E\left[\left(\sigma_{s i}^{-1}\left(S_{i t}-\mu_{s i}\right) \sigma_{s j}^{-1}\left(S_{j t}-\mu_{s j}\right)\right)-\rho_{s}\right]=0
$$

$\mu_{\mathrm{s}}$ is the mean and $\sigma_{\mathrm{s}}$ the standard deviation of the series $\left(\mathrm{S}_{\mathrm{it}}\right)$ and $\left(\mathrm{S}_{\mathrm{jt}}\right)$. 
This yields the following estimator:

$$
\frac{1}{T} \sum_{t=1}^{T}\left[\left(\hat{\sigma}_{s i}^{-1}\left(S_{i t}-\hat{\mu}_{s i}\right) \hat{\sigma}_{s j}^{-1}\left(S_{j t}-\hat{\mu}_{s j}\right)\right)-\hat{\rho}_{s}\right]=0
$$

We use the heteroskedastic and autocorrelation consistent (HAC) estimation procedure of Newey and West (1987) with Bartlett weights. The statistical significance can therefore be contrasted using the t-ratio.

The two synchronization indicators fall into the same range (Table 3). Roughly $69 \%$ of the time the HP and GDP are in the same cycle phase, and the t-student test verifies that there is a significant pro-cyclical co-movement. However, the divergence in the duration and deepness found in the preceding section may imply the existence of a lead (lag) relationship.

Table 3

Synchronization indicators

\begin{tabular}{|l|c|c|}
\hline & Concordance index (I) & t-student \\
\hline GDP-HP & 0.691 & 3.352628 \\
\hline
\end{tabular}

Source: Own elaboration.

To confirm that the non-contemporaneous correlation exists, we compute cross-correlation coefficients in Table 4. The reference series is the business cycle (GDP). The (t-k) columns report the correlation between the fluctuations of the GDP in period $t$ and the fluctuations of the HP in period $(\mathrm{t}-\mathrm{k})$. The $(\mathrm{t}+\mathrm{k})$ columns report the correlation between the GDP fluctuations in period $t$ and the fluctuations of the HP in period $(\mathrm{t}+\mathrm{k})$. According to the coefficients, in most cases the cross-correlation is positive, which confirms the pro-cyclical relationship. In addition, the highest index is the contemporaneous one, followed by one quarter and two quarters (t-k) indexes, which might indicate that a certain leading behavior of the housing prices exists relative to the business cycle. However, the important difference shown by the $(\mathrm{t}+\mathrm{k})$ coefficients, with the contemporaneous one standing out from the rest, might also mean a different leading/lagging linkage in each phase, expansion and contraction.

To confirm the previous affirmation, the average lag (lead) of the HP turning points with regard to those of the GDP is calculated. In the troughs the housing prices lead the GDP by roughly 3 quarters, and in the peaks they are quite contemporaneous (the average lead of the HP is 0.43 quarters). The figures confirm those of the previous cross-correlation analysis. The leading/lagging relationship is not the same in the expansion and in the contraction phases. The HP leads the GDP in the expansion phases, and in the contraction phases the two series are coincident. 
Table 4

Cross-correlations $^{a}$

\begin{tabular}{|c|c|c|}
\hline & \multicolumn{2}{|c|}{ GDP/HP } \\
\hline $\mathbf{K}^{\mathbf{b}}$ & $\mathbf{t}-\mathbf{k}$ & $\mathbf{t + k}$ \\
\hline 0 & $0.7553^{\star}$ & $0.7553^{\star}$ \\
\hline 1 & $0.7290^{\star}$ & $0.5386^{\star \star}$ \\
\hline 2 & $0.7234^{\star}$ & $0.5373^{\star \star}$ \\
\hline 3 & $0.6393^{\star}$ & 0.3769 \\
\hline 4 & $0.5529^{\star}$ & 0.2646 \\
\hline 5 & $0.4158^{\star}$ & 0.1166 \\
\hline 6 & $0.3098^{\star}$ & 0.0276 \\
\hline 7 & $0.1624^{\star \star}$ & -0.0919 \\
\hline 8 & 0.0598 & -0.1328 \\
\hline
\end{tabular}

${ }^{a}$ GDP reference series;

${ }^{b}+k(-k)$ denotes a lag (lead) with respect to the reference series (GDP)

* Significant at the 1\% level; ** Significant at the 5\% level.

Source: Own elaboration.

For a more robust analysis, we study the (lagging/leading) causality between cycles using the Granger causality test. To carry it out, we use a VAR model:

$$
y_{t}=\alpha+\phi_{1} y_{t-1}+\alpha+\phi_{2} y_{t-2}+\ldots+\phi_{k} y_{t-k}+\varepsilon_{t}
$$

where $y_{t}$ are $(2 \times 1)$ vectors of the GDP and HP cyclical components, $\phi$ are $(2 \times 2)$ coefficient matrices, $\alpha$ is a $(2 \times 1)$ vector of constants and $\varepsilon_{t}$ is a 2-dimensional white noise process.

We begin by estimating a model that includes the complete sample (model 1). If the results show that the causality between business and housing price cycles is bi-directional, we assume that it expresses a non-homogeneous linkage throughout the entire sample. To demonstrate this assumption, we estimate two alternative models. One of them takes the HP as the reference series, and it will look for the causality between the HP expansion phases and the values of the GDP in these quarters (model 2). We want to corroborate whether the HP leads the GDP in the expansion phases. The other model (model 3) again takes the HP as the reference series, and it estimates the causality between the HP contraction phases and the GDP values in these quarters. In this case we want to determine whether the causality between HP and GDP does not exist because of their contemporaneous relationship.

We work with cyclical components; consequently, the series do not have unit roots. In the three models we adopt the following sequence. We use the AIC and SC information criteria to specify the order of the lags in the equations. If the two criteria do not agree, we choose the lag of which the residuals are 
uncorrelated; we check this non-correlation by applying the Ljung-Box test. Finally, the residual tests are carried out.

\section{Model 1: complete sample}

According to the AIC, the order of the VAR is set at 4 , and according to the SC it is set at 3 (Table A.1 in the appendix). If the order of the lags is 3, we cannot reject the null hypothesis that the residuals are uncorrelated, so the order 3 is appropriate for the VAR lag length. The residual tests show that the model is well specified.

Table 5 presents the results of the Granger causality F-test. Looking at the pvalue for the null hypothesis (5\% significant level), it is possible to conclude that Granger causality exists between the business cycle and the housing prices and that it is bi-directional. However, the cointegration regression (Table A.2 in the appendix) indicates that the only significant and positive coefficient is that of the business cycle with respect to the second lag of the housing prices. Again, the outcomes might be hiding a different relationship depending on the cycle phases of the two series.

\section{Table 5}

Granger causality: model 1

\begin{tabular}{|l|c|}
\hline \multicolumn{1}{|c|}{ Null Hypothesis: } & Probability \\
\hline HP does not Granger Cause GDP & $7.1 \mathrm{E}-06$ \\
\hline GDP does not Granger Cause HP & $5.1 \mathrm{E}-05$ \\
\hline
\end{tabular}

Source: Own elaboration.

\section{Model 2: HP in expansion}

According to the AIC and the SC, the order of the VAR is set at 2 (Table A.3 in the appendix). The residual tests show that the model is well specified.

Table 6 presents the results of the Granger causality F-test. From the p-value for the null hypothesis (5\% significant level), it is possible to conclude that the housing prices Granger cause the business cycle. However, the business cycle does not Granger cause the housing prices. Thus, the causality is uni-directional. The cointegration regression (Tables A.4 in the appendix) indicates that the business cycle has significant and positive coefficients with respect to the second lag of the housing prices.

The high levels of one and two quarters of the cross-correlation leading indexes of the HP (Table 4), the average lead found in the expansion phases ( 3 quarters), the causality detected (Table 6) and the cointegration estimation (Table A.4) allow us to conclude that the HP leads the GDP in expansion phases. 
Table 6

Granger causality: model 2

\begin{tabular}{|l|c|}
\hline \multicolumn{1}{|c|}{ Null Hypothesis: } & Probability \\
\hline HP expansions do not Granger cause GDP & 0.00464 \\
\hline GDP does not Granger cause HP expansions & 0.15124 \\
\hline
\end{tabular}

Source: Own elaboration.

\section{Model 3: HP in contraction}

According to the AIC, the order of the VAR is set at 3 , and according to the SC it is set at 1 (Table A.5 in the appendix). If the order of the lags is 1 , we cannot reject the null hypothesis that the residuals are uncorrelated, so the order 1 is appropriate for the VAR lag length. The residual tests show that the model is well specified.

Table 7 presents the results of the Granger causality F-test. Considering the p-value for the null hypothesis (5\% significant level), it is possible to conclude that the HP does not cause the GDP and vice versa. The cointegration regression (Table A.6 in the appendix) indicates that there is no statistically significant coefficient.

The high level of contemporaneous cross-correlation detected in Table 4, the absence of an average lead in contraction phases ( 0.43 quarters), the absence of causality (Table 7) and the cointegration estimation (Table A.6) lead us to conclude that the HP and GDP are well synchronized in the contraction phases.

Table 7

Granger causality: model 3

\begin{tabular}{|l|c|}
\hline \multicolumn{1}{|c|}{ Null Hypothesis: } & Probability \\
\hline HP contractions do not Granger cause GDP & 0.34448 \\
\hline GDP does not Granger cause HP contractions & 0.13934 \\
\hline
\end{tabular}

Source: Own elaboration.

\section{WHICH ECONOMIC FACTS LIE BEHIND SUCH A RELATIONSHIP?}

Rünstler and Velke (2016) indicate that the Spanish business cycle lags the housing price cycle. ${ }^{3}$ However, our paper finds evidence of asymmetric behavior between the expansion and the contraction phases. This result is not as odd as it might seem at first glance. Dufrénot and Malik (2010) advocate a similar non-homogeneous relationship in the US, UK and Spanish economies

\footnotetext{
${ }^{3}$ The same result is observed in France but not in the rest of the countries analysed in the study (the USA, the UK, Germany and Italy).
} 
for the period 1980-2008. Some stylized facts concerning the Spanish economy consistent with the literature on this subject may help us to understand our outcomes.

Starting with the expansion phases, Álvarez and Cabrero (2010) and Sala et al. (2016) state that the leading nature of the residential investment with respect to the GDP pushes forward the Spanish economic activity and the housing prices; however, according to our results, the housing prices are prone to increase and they lead the business cycle. ${ }^{4}$ Different factors drive this behavior. Calza et al. (2009) and Ferrara and Vigna (2009) suggest that countries such as Spain, where sophisticated financial instruments for housing financing have been increasing, have financial institutions that are more willing to increase the amount of initial housing loans, because the market value of the guarantee also appreciates. Moreover, the fewer restrictions on housing financing and the further competition among financial institutions shown by the Spanish economy have contributed to raising the housing loans (Martínez and Maza 2003; IMF 2008; Rubio and Carrasco-Gallego 2017). The facts that households can obtain new funds and that people in Spain present a strong wish to own a house increase the housing investment; consequently, the GDP increases too. ${ }^{5}$

However, housing has a long production process that means that its supply is relatively rigid. As noted by Díaz and Jerez (2010), the rigidity of the supply of houses raises their price, implying that buyers take longer to trade and sellers try to trade faster. The result is a lagging increase in the residential investment regarding prices. The importance of the Spanish construction sector makes these supply constraints very significant in the economy, implying that housing prices tend to recover more quickly than the GDP. Furthermore, it is worth remarking that the lagged recovery of the GDP is not only because of the supply constraints but also because of the high expectations of future housing price increases (Shiller 2007). The expectations of revalorization produce speculative phenomena, launching the willingness to invest in housing in the future.

The consequences for the economic activity do not finish in the previous stage. Catte et al. (2004) note that the increase in housing prices has a significant wealth effect on consumption and is strongest in countries that have a large, complete and efficient mortgage market. They incorporate these properties into a synthetic

\footnotetext{
${ }^{4}$ The trend of the quick recovery of the Spanish housing prices can be highlighted by comparing their evolution in the last downturn identified in this study with that forecasted by the model estimated in the study by Bracke (2013). According to our Table 1, the last contraction finished in 2013/1Q, while the model predicted a 63\% chance that the downturn would end at the beginning of 2015.

${ }^{5}$ Huber (2016), over the period 1970-2013, establishes the Spanish homeownership rate as roughly $80 \%$. It is the highest rate of the 18 OECD countries analyzed in this study. In fact, Rünstler and Vlekke (2016) indicate that high rates of private homeownership affect the financial cycle too. Thus, countries like Spain present larger and longer financial cycles.
} 
"completeness" index of the mortgage markets to calculate the correlation between this index and the prices/consumption. The Spanish index reaches 66\% and confirms the existence of the wealth effect, which pushes consumption and again the GDP. ${ }^{6}$

On the other hand, in contraction phases the housing prices move synchronously with the business cycle. Here we can also underline different reasons for the housing prices' coincidence with the business cycle in the face of declining shocks in real estate. First, the lending conditions and standards are harder in downturns than in upturns (Akin et al. 2014), tending to shorten credit. Moreover, in an uncertain economic framework, banks are less willing to grant new credit (Becker and Ivashina 2014); if, in addition, they are working in an environment characterized by a weakening of their balance sheets, the credit crunch is more acute (Bernake 1983). The effectiveness of the credit crunch over economic activity is larger than that of the increase, because in this context the household disposition to demand credit does not play any role. The credit crunch implies a decrease in housing sales and presses their prices downward. As Leamer (2008) remarks, the decline in the volume of sales brings a decline in jobs in construction, finance, and real estate brokerage, which in Spain, due its excessive dependence on real estate, produces a great effect on the GDP.

Furthermore, and more important from the point of view of our results, is that the housing prices react contemporaneously with the business cycle, because Spain shows a higher level of adjustable interest rates than other European countries. ${ }^{7}$ Ferrara and Vigna (2009) point out that a larger share of new housing loans with an adjustable rate implies a quicker collapse of the housing prices. Variable interest rates strengthen the financial accelerator consequences, making Spanish households more sensitive to credit crunch episodes. Facing a hardening in the lending conditions, in economies in which variable interest rates dominate, the fear of a shock drives prices downward faster than they move upward. It is the housing market's answer to try to cushion the expected effect on the demand. In addition, Hartmann (2015) highlights that economies such as Spain, in which real estate and construction are important sectors of the real economy, the indivisibility of real estate has more influence on the price reactions during downturns. The final outcome is a synchronized co-movement between the housing prices and the GDP.

However, as we can see in Table 2, the HP contraction amplitude is lower

\footnotetext{
${ }^{6}$ Another synthetic indicator of mortgage market developments can be found in IMF (2008). The index moves between 0 and 1 . Higher values indicate a more developed mortgage market. The Spanish ratio is 0.4 , which is a medium value but higher, for instance, than that of the two largest euro area countries, Germany (0.28) and France (0.23).
}

7 According to Eurostat data, the average percentage was higher than $80 \%$ in the period 2003-2016, while in the eurozone as a whole it was roughly $38 \%$. 
than the GDP amplitude; therefore, the data show that on average, during the period analyzed, the adjustment of volume was greater than the adjustment of prices. A fall in prices does not seem to have been achieved to cushion the fall in demand. In our opinion hardening credit conditions cause a stronger demand shock in Spain, because, as indicated by Rubio and Carrasco-Gallego (2017), its propensity to borrow is higher than that of other countries; especially, it is higher than that of the Euro area countries.

\section{CONCLUSIONS}

This paper analyzes the links between the housing prices and the business cycle in the Spanish economy. We calculate the turning points of the housing price and business cycles and their main features to check the nature of the relationship of the two cycles. We estimate the synchronization and the causality and provide the economic facts that are behind the interaction of the cycles found.

The study yields the following main results. First, business cycles are longer than housing price cycles overall; however, this is more evident in expansion than in contraction phases. Furthermore, the housing price expansion phases show a greater amplitude and the contraction phases show a smaller amplitude than those of the GDP. In expansion phases the increase in the prices is more important than that in the volume, and in contraction phases the decrease in the prices is less important than that in the volume. Housing prices cycles seem to be more sensitive than business cycles, especially in the recovery processes.

Second, we find that housing price co-movements are pro-cyclical regarding the business cycle. However, the divergence in the duration and deepness indicate that a non-contemporaneous relationship might exist. The crosscorrelation coefficients and the average lag of the housing price turning points suggest that a non-homogeneous relationship exists between the cycles. Namely, the figures indicate that the housing prices lead the GDP in expansion phases and the co-movements are contemporaneous in contraction phases.

Third, we check the robustness of this result using the Granger causality test through VAR model estimation. We distinguish among three models that allow us to corroborate the non-homogeneous linkages between the housing and the business cycle depending on the cyclical phases. The Granger causality points out that the housing price cycle leads the business cycle in expansion phases and that the two cycles are well synchronized in the contraction phases.

In accordance with the literature, it is possible to stress some economic facts that allow us to explain our results. The leading behavior of the housing price cycle in expansion phases is related to the fact that the Spanish economy has shown few restrictions on housing financing, a temporal process of important development of its financial instruments and a high level of competition among 
institutions. All of this, added to the fact that Spanish households present a strong wish for homeownership, pushes forward the residential investment and consequently the economic activity. However, the housing prices lead this increase due to the housing supply constraints and the speculation triggered by the expectations of future housing price growth. In this context, in which buyers take longer to trade and sellers try to trade faster, the result is the housing price behavior leading the business cycle.

In contraction phases the lending conditions and standards harden, tending to shorten credit. The effectiveness of a credit crunch is larger than that of a credit boom, because households continue to wish for homeownership but cannot find funds. The housing prices are put under downward pressure by the credit crunch, and at the same time the downward credit has a great effect on the Spanish economic growth. The decline in construction sector jobs, finance and real estate brokerages affects the core of the Spanish economic activity. The synchronized fluctuations between housing prices and business cycles come from both the fact that Spain shows a higher level of adjustable interest rates than other European countries and the great influence of the indivisibility of real estate on the price reactions.

Taking account of the fact that the construction sector and real estate sector are so important in the fluctuations of the Spanish economic activity, housing prices become a strategic variable that should be in the focus of policymakers' decisions. Following our results, housing prices are prone to increase more quickly and decrease synchronously regarding the GDP. We also found that the depth of the expansions is greater in the housing prices than in the GDP, while in contractions the opposite occurs. Therefore, in expansion phases the volume adjustments are bigger than the price adjustments, and in contraction phases they are smaller. The risk of a boom is greater than the risk of a bust, making Spain very sensitive to housing bubbles. It is indubitable that this is an important outcome that should be taken into account by policymakers in the development of their economic policy measures.

\section{BIBLIOGRAPHY REFERENCES}

AGNELLO, L. and SHUKNECHT, L. (2011). "Booms and busts in housing markets: Determinants and implications". Journal of Housing Economics, 20 (3), pp. 171-190.

AKIN, O.; GARCÍA MONTALVO, J.; GARCÍA VILLAR, J.; PEYDRÓ J.L. and RAYA, J.M. (2014). "The real estate and credit bubble: evidence from Spain". SERIES, 5 (1-2), pp. 223-243.

ÁlVAREZ, L.J.; BULligAN, G.; CABRERO, A.; FERRARA, L. and STAHL, H. (2009). Housing cycles in the major euro area countries. Banque de France Working Paper 269. 
ÁLVAREZ, L.J. and CABRERO, A. (2010). Does housing really lead the business cycle? Banco de España Documento de trabajo, 1024.

BECKER, B. and IVASHINA, V. (2014). "Cyclicality of Credit Supply: Firm Level Evidence". Journal of Monetary Economics, 62, pp. 76-93.

BERNANKE, B.S. (1983). "Nonmonetary effects of the financial crisis in the propagation of the great depression". American Economic Review, 73 (3), pp. 257-276.

BLANCO, F.; MARTÍN, V. and VÁZQUEZ, G. (2016). "Regional house price convergence in Spain during the housing boom". Urban Studies, 53(4), pp. 775-798.

BRACKE, P. (2013). "How long do housing cycles last? A duration analysis for 19 OECD countries". Journal of Housing Economics, 22(3), pp. 213-230.

BRY, G. and BOSCHAN. CH. (1971). Cyclical analysis of time series: selected procedures and computer programmes. New York: National Bureau of Economic Research.

CALZA, A.; MONACELLI, T. and STRACCA. L. (2009). HouSing Finance and Monetary Policy. European Central Bank Working Paper 1069.

CATTE, P.; GIROUARD, N.; PRICE, R. and ANDRÉ, CH. (2004). Housing markets, wealth and the business cycle. OECD Economics Working Papers, 394.

CERON, J. and SUAREZ, J. (2006). Hot and cold housing markets: international evidence. CEMFI Working Paper 0603.

CLAESSENS, S.; KOSE, M. A. and TERRONES, M. E. (2009). "What happens during recessions, crushes and bust?. Economic Policy, 24(60), pp. 653-700.

CORRADIN, S. and FONTANA, A. (2013). House price cycles in Europe. European Central Bank Working Paper, 1613.

DAMEN, S.; VASTMANS, F. and BUYST, E. (2016). "The effect of mortgage interest and mortgage characteristics on house prices". Journal of Housing Economics, 34, pp. 1529.

DE LA FUENTE, A. (2016). Series enlazadas y otros agregados de Contabilidad Nacional para España 1955-2014. FEDEA and Instituto de Análisis Económico (CSIC).

DÍAZ, A. and JEREZ, B. (2010). House prices, sales, and time on the market: a searchtheoretic framework. Universidad Carlos III Working Paper Economic Series 10-33.

DUFRÉNOT, G. and MALIK, S. (2010). The changing role of house price dynamics over the business cycle. Banque de France Document du Travail, 309.

ENGSTED, T.; HVIID, S.J. and PEDERSEN, T.Q. (2016). "Explosive bubbles in house prices? Evidence from the OECD countries" in Journal of International Financial Markets, Institutions \& Money, 40, pp. 14-25.

FERRARA, L. and VIGNA, O. (2009). Cyclical relationships between GDP and housing market in France: facts and factors at play. Banque de France Document de travail, 268.

FIORENTINI, G. and PLANAS, CH. (2003). User manual BUSY-Program, EC Fifth Framework Program, Joint Research Centre of the European Commission, Ispra.

GARCÍA MONTALVO, J. (2001). "Un análisis empírico del crecimiento del precio de la vivienda en las comunidades autónomas españolas". Revista Valenciana de Economía y Hacienda, 2, pp. 117-138.

GARCÍA MONTALVO, J. (2009). "Financiación inmobiliaria, burbuja crediticia y crisis financiera: Lecciones a partir de la recesión de 2008-2009". Papeles de Economía Española, 122, pp. 66-85. 
HARDING, D. and PAGAN, A. (2002). "Dissecting the Cycle: a Methodological Investigation". Journal of Monetary Economics, 49(2), pp. 365-381.

HARDING, D. and PAGAN, A. (2006). "Synchronization of cycles". Journal of Econometrics, 132(1), pp. 59-79.

HARTMANN, P. (2015). Real estate markets and macroprudential policy in Europe. European Central Bank Working paper Series, 1796.

HIRATA, H.; M. KOSE, A.; OTROK, CH. and TERRONES, M. E. (2012). Global house price fluctuations: synchronization and determinants. NBER Working Paper Series, 18362.

HUANG, M. (2017). "Vulnerabilities to housing bubbles: Evidence from linkages between housing prices and income fundamentals". International Finance, 20(1), pp. 64-91.

HUBER, S. J. (2016). "Housing booms and busts: convergence and divergence in OECD countries". Universitat Pompeu Fabra, mimeo.

IGAN, D.; KABUNDI, A.; NADAL DE SIMONE, F.; PINHEIRO, M. and TAMIRISA, N. (2011). "Housing, credit, and real activity cycles: Characterisitcs and comovements". Journal of Housing Economics, 20, pp. 210-231.

INTERNATIONAL MONETARY FUND (IMF) (2008). "The changing housing cycle and the implications for monetary policy". World Economic Outlook. Housing and the Business Cycle (pp. 103-132). Washington, D.C: IMF,.

KYDLAND, F. E., RUPERT, P. and ŠUSTEK, R. (2016). "Housing dynamics over the business cycle". International Economic Review, 57(4), pp. 1149-1177.

KISHOR, N. K. and MARFATIA, H.A. (2017). "The Dynamic Relationship Between Housing Prices and the Macroeconomy: Evidence from OECD Countries". The Journal of Real Estate Finance and Economics, 54(2), pp. 237-268.

LEAMER, E. (2008). "Housing IS the Business Cycle". Housing, Housing Finance and Monetary Policy, Symposium sponsored by the Federal Reserve of Kansas City. (Revised and updated for the Encyclopedia of Finance, 2010).

LEAMER, E.E. (2009). "Homes and Cars: Why are the Cycles in Homes and Consumer Durables so Similar?". Advances in Economic Analysis \& Policy, Berkeley Electronic Press 9, 3 (Symposium), article 5.

LEAMER, E. E. (2015). "Housing really is the business cycle: What survives the lessons of 2008-09?". Journal of Money, Credit and Banking supplement to vol 47(1), pp. 4450.

LING, D. C.; OOI, J.T.L. and LE, T.T.T. (2015). "Explaining house price dynamics: Isolating the role of nonfundamentals". Journal of Money, Credit and Banking, supplement to vol. 47(1), pp. 87-125.

MARTÍNEZ, J. and MAZA, L.A. (2003). Analysis of house prices in Spain. Banco de España Documento de Trabajo, 0307.

MIAN, A.; SUFI, A. and VERNER, E. "Household Debt and Business Cycles Worldwide". In The Quarterly Journal of Economics, qjx017, https://doi.org/10.1093/qje/qjx017.

NEWEY, W. K. and. WEST, K. D. (1987). "A simple, positive semi-definite, heteroskedasticity, and autocorrelation consistent covariance matrix". Econometrica, 55(3), pp. 703-708.

RUBIO, M. and CARRASCO-GALLEGO, J.A. (2017). "Spain and the crisis: housing prices, credit and macroprudential policies". The Singapore Economic Review, 62(1), 109-133. 
RÜNSTLER, G. and VLEKKE, M. (2016). Business, housing and credit cycles. European Central Bank Working Paper Series, 1915.

SALA-RIOS, M.; TORRES-SOLÉ, T. and FARRÉ-PERDIGUER, M. (2016). "Credit and business cycles' relationship: evidence from Spain”. Portuguese Economic Journal, 15(3), pp. 149-171.

SICHEL, D. (1993). "Business cycle asymmetry: a deeper look". Economic Inquiry, 31(2), pp. 224-236.

SHILLER, R.J. (2007). Understanding recent trends in house prices and home ownership. NBER Working Paper Series, 13553.

VOGIAZAS, S. and ALEXIOU, C. (2017). "Determinants of Housing Prices and Bubble Detection: Evidence from Seven Advanced Economies". Atlantic Economic Journal, 45(1), pp. 119-131. 


\section{Appendix}

Table A.1.

Johansen cointegration test and VAR lag order selection criteria. Model 1

\begin{tabular}{|c|c|c|}
\hline Lag & AIC & SC \\
\hline 0 & 25.63491 & 25.67079 \\
1 & 23.09973 & 23.20740 \\
2 & 22.87946 & 23.05891 \\
3 & 22.60905 & $22.86027^{\star}$ \\
4 & $22.59832^{\star}$ & 22.92131 \\
\hline
\end{tabular}

* Indicates lag order selected by the criterion.

AIC: Akaike information criterion.

SC: Schwarz information criterion.

Source: Own elaboration.

Table A.2.

Cointegration regression. Model 1

\begin{tabular}{|c|c|c|}
\hline \multicolumn{3}{|c|}{ Standard errors in ( ) \& t-statistics in [ ] } \\
\hline Cointegrating Eq: & CointEq1 & \\
\hline $\mathrm{GDP}(-1)$ & 1.000000 & \\
\hline $\mathrm{HP}(-1)$ & $\begin{array}{c}-620.9641 \\
(69.3950) \\
{[-8.94826]}\end{array}$ & \\
\hline $\mathrm{C}$ & -50.31995 & \\
\hline Error Correction: & $\mathrm{D}(\mathrm{GDP})$ & $\mathrm{D}(\mathrm{HP})$ \\
\hline CointEq1 & $\begin{array}{c}-0.075795 \\
(0.04294) \\
{[-1.76497]}\end{array}$ & $\begin{array}{c}0.000351 \\
(7.9 \mathrm{E}-05) \\
{[4.46199]}\end{array}$ \\
\hline $\mathrm{D}(\mathrm{GDP}(-1))$ & $\begin{array}{c}-0.176202 \\
(0.08025) \\
{[-2.19563]}\end{array}$ & $\begin{array}{c}-1.63 E-07 \\
(0.00015) \\
{[-0.00111]}\end{array}$ \\
\hline $\mathrm{D}(\mathrm{GDP}(-2))$ & $\begin{array}{c}0.223421 \\
(0.07383) \\
{[3.02606]}\end{array}$ & $\begin{array}{c}0.000409 \\
(0.00014) \\
{[3.02612]}\end{array}$ \\
\hline $\mathrm{D}(\mathrm{GDP}(-3))$ & $\begin{array}{c}-0.259825 \\
(0.07556) \\
{[-3.43872]}\end{array}$ & $\begin{array}{r}-0.000326 \\
(0.00014) \\
{[-2.35824]}\end{array}$ \\
\hline $\mathrm{D}(\mathrm{HP}(-1))$ & $\begin{array}{c}-0.142577 \\
(42.4158) \\
{[-0.00336]}\end{array}$ & $\begin{array}{l}0.379975 \\
(0.07768) \\
{[4.89167]}\end{array}$ \\
\hline $\mathrm{D}(\mathrm{HP}(-2))$ & $\begin{array}{c}138.6658 \\
(44.2875) \\
{[3.13104]}\end{array}$ & $\begin{array}{c}0.185818 \\
(0.08111) \\
{[2.29106]}\end{array}$ \\
\hline $\mathrm{D}(\mathrm{HP}(-3))$ & $\begin{array}{l}55.83871 \\
(45.4851) \\
{[1.22763]}\end{array}$ & $\begin{array}{c}0.183378 \\
(0.08330) \\
{[2.20145]}\end{array}$ \\
\hline
\end{tabular}


Table A.2. (Continue)

Cointegration regression. Model 1

\begin{tabular}{|lcc|}
\hline \multicolumn{3}{|c|}{ Standard errors in ( ) \& t-statistics in [ ] } \\
\hline \multicolumn{1}{|c|}{ Error Correction: } & D(GDP) & D(HP) \\
\hline \multicolumn{1}{|c|}{ C } & 79.42479 & 0.089317 \\
& $(122.018)$ & $(0.22346)$ \\
\hline R-squared & {$[0.65093]$} & {$[0.39971]$} \\
Adj. R-squared & 0.385209 & 0.294394 \\
Sum sq. resids & 0.359744 & 0.265168 \\
S.E. equation & $4.44 E+08$ & 1489.952 \\
F-statistic & 1621.337 & 2.969223 \\
Log likelihood & 15.12715 & 10.07292 \\
Akaike AlC & -1555.267 & -439.6881 \\
Schwarz SC & 17.66403 & 5.058622 \\
Mean dependent & 17.80759 & 5.202177 \\
S.D. dependent & 89.04416 & 0.158858 \\
\hline Determinant Residual Covariance & 2026.266 & 3.463767 \\
Log Likelihood & & 20937601 \\
Log Likelihood (d.f. adjusted) & & -1985.967 \\
Akaike Information Criteria & & -1994.154 \\
Schwarz Criteria & & 22.73620 \\
\hline
\end{tabular}

Source: Own elaboration.

Table A.3.

VAR lag order selection criteria. Model 2

\begin{tabular}{|c|c|c|}
\hline Lag & AIC & SC \\
\hline 0 & 25.28095 & 25.33803 \\
1 & 24.13488 & 24.30611 \\
2 & $24.17815^{\star}$ & $24.46354^{*}$ \\
3 & 24.23808 & 24.63763 \\
4 & 24.29456 & 24.80826 \\
\hline
\end{tabular}

* Indicates lag order selected by the criterion.

AIC: Akaike information criterion.

SC: Schwarz information criterion.

Source: Own elaboration. 
Table A.4.

Cointegration regression. Model 2

\begin{tabular}{|c|c|c|}
\hline \multicolumn{3}{|c|}{ Standard errors in () \& t-statistics in [ ] } \\
\hline Cointegrating Eq: & \multicolumn{2}{|c|}{ CointEq1 } \\
\hline $\operatorname{GDP}(-1)$ & 1.000000 & \\
\hline \multirow[t]{3}{*}{ EXPANSIONHP(-1) } & -542.1560 & \\
\hline & $(80.2496)$ & \\
\hline & {$[-6.75587]$} & \\
\hline C & -932.9922 & \\
\hline Error Correction: & $\mathrm{D}(\mathrm{GDP})$ & D(EXPANSIONHP) \\
\hline \multirow[t]{3}{*}{ CointEq1 } & -0.128357 & 0.001008 \\
\hline & $(0.11338)$ & $(0.00028)$ \\
\hline & {$[-1.13214]$} & {$[3.55017]$} \\
\hline \multirow[t]{3}{*}{$\mathrm{D}(\mathrm{GDP}(-1))$} & -0.090081 & -0.000567 \\
\hline & $(0.13443)$ & $(0.00034)$ \\
\hline & {$[-0.67010]$} & {$[-1.68382]$} \\
\hline \multirow[t]{3}{*}{$\mathrm{D}(\mathrm{GDP}(-2))$} & 0.006338 & -0.000164 \\
\hline & $(0.13814)$ & $(0.00035)$ \\
\hline & {$[0.04588]$} & {$[-0.47419]$} \\
\hline \multirow[t]{3}{*}{ D(EXPANSIONHP(-1)) } & 2.236057 & 0.227967 \\
\hline & $(55.8444)$ & $(0.13988)$ \\
\hline & {$[-0.04004]$} & [ 1.62969$]$ \\
\hline \multirow[t]{3}{*}{ D(EXPANSIONHP(-2)) } & 2.49289 & 0.079692 \\
\hline & $(53.9183)$ & $(0.13506)$ \\
\hline & [ 2.39862] & {$[0.59006]$} \\
\hline \multirow[t]{3}{*}{$\mathrm{C}$} & -98.08344 & -0.315140 \\
\hline & $(2.34356)$ & $(0.58704)$ \\
\hline & {$[-0.41852]$} & {$[-0.53683]$} \\
\hline R-squared & 0.048113 & 0.162986 \\
\hline Adj. R-squared & -0.010646 & 0.111318 \\
\hline Sum sq. resids & $3.84 \mathrm{E}+08$ & 2408.552 \\
\hline S.E. equation & 2176.948 & 5.453000 \\
\hline F-statistic & 0.818823 & 3.154511 \\
\hline Log likelihood & -788.9933 & -267.9056 \\
\hline Akaike AIC & 18.27571 & 6.296681 \\
\hline Schwarz SC & 18.44577 & 6.466743 \\
\hline Mean dependent & -92.36203 & -0.319935 \\
\hline S.D. dependent & 2165.452 & 5.784454 \\
\hline Determinant Residual Covariance & & $1.02 \mathrm{E}+08$ \\
\hline Log Likelihood & & -1042.882 \\
\hline Log Likelihood (d.f. adjusted) & & -1049.099 \\
\hline Akaike Information Criteria & & 24.43905 \\
\hline Schwarz Criteria & & 24.83586 \\
\hline
\end{tabular}

Source: Own elaboration. 
Table A.5.

Johansen cointegration test and VAR lag order selection criteria. Model 3

\begin{tabular}{|c|l|l|}
\hline Lag & AIC & SC \\
\hline 0 & 25.78530 & 25.84199 \\
1 & 24.83627 & $25.00633^{*}$ \\
2 & 24.83913 & 25.12257 \\
3 & $24.79107^{\star}$ & 25.18788 \\
4 & 24.87866 & 25.38884 \\
\hline
\end{tabular}

* Indicates lag order selected by the criterion.

AIC: Akaike information criterion.

SC: Schwarz information criterion.

Source: Own elaboration.

Table A.6.

Cointegration regression. Model 3

\begin{tabular}{|c|c|c|}
\hline \multicolumn{3}{|c|}{ Standard errors in () \& t-statistics in [] } \\
\hline Cointegrating Eq: & CointEq1 & \\
\hline CONTRACCIONHP(-1) & 1.000000 & \\
\hline $\operatorname{GDP}(-1)$ & $\begin{array}{c}-0.001767 \\
(0.00034) \\
{[-5.20916]}\end{array}$ & \\
\hline $\mathrm{C}$ & -1.694725 & \\
\hline Error Correction: & $\mathrm{D}(\mathrm{GDP})$ & D(EXPANSIONHP) \\
\hline CointEq1 & $\begin{array}{l}-29.90366 \\
(57.2078) \\
{[-0.52272]}\end{array}$ & $\begin{array}{c}-0.517941 \\
(0.14736) \\
{[-3.51477]}\end{array}$ \\
\hline $\mathrm{D}(\mathrm{GDP}(-1))$ & $\begin{array}{c}-0.424049 \\
(0.14432) \\
{[-2.93823]}\end{array}$ & $\begin{array}{c}-0.000265 \\
(0.00037) \\
{[-0.71343]}\end{array}$ \\
\hline D(CONTRACTIONHP(-1)) & $\begin{array}{l}104.1269 \\
(58.1698) \\
{[1.79005]}\end{array}$ & $\begin{array}{l}0.134809 \\
(0.14984) \\
{[0.89969]}\end{array}$ \\
\hline C & $\begin{array}{r}182.7981 \\
(290.716) \\
{[0.62878]} \\
\end{array}$ & $\begin{array}{l}0.357010 \\
(0.74885) \\
{[0.47674]} \\
\end{array}$ \\
\hline R-squared & 0.094527 & 0.135172 \\
\hline Adj. R-squared & 0.062569 & 0.104648 \\
\hline Sum sq. resids & $6.39 \mathrm{E}+08$ & 4236.732 \\
\hline S.E. equation & 2740.810 & 7.060022 \\
\hline F-statistic & 2.957857 & 4.428468 \\
\hline Log likelihood & -828.7640 & -298.1851 \\
\hline Akaike AIC & 18.71380 & 6.790676 \\
\hline Schwarz SC & 18.82565 & 6.902525 \\
\hline Mean dependent & 161.9186 & 0.357746 \\
\hline S.D. dependent & 2830.800 & 7.461209 \\
\hline Determinant Residual Covariance & & $1.83 \mathrm{E}+08$ \\
\hline Log Likelihood & & -1094.997 \\
\hline Log Likelihood (d.f. adjusted) & & -1099.090 \\
\hline Akaike Information Criteria & & 24.92336 \\
\hline Schwarz Criteria & & 25.20299 \\
\hline
\end{tabular}

Source: Own elaboration. 
